This paper is a post-print of an article published in Politics 20(3): 129-135. The definitive version is available at: $\underline{\text { http://dx.doi.org/10.1111/1467-9256.00122 }}$

\title{
Power and Responsibility: Should We Spare the King's Head?
}

\author{
Andrew Schaap
}

Michel Foucault calls for the head of the king in political theory. In doing so he seems to sever the concept of power from its relation to human responsibility. However, for theoretical 'monarchists' such as Stephen Lukes, the whole point of identifying a relationship of power is to fix responsibility for its exercise. Given the contingency of political action, I agree with Foucault that it is not always possible to attribute responsibility for the effects of power to a particular agent. However, Foucault stretches the concept of power too far beyond its ethical association with human responsibility. Consequently, the idea of power becomes practically meaningless.

Should we spare the king's head? Perhaps it is too late to pose this question. Perhaps the king has already been executed. The idea that a particular group of people in society might hold power over another group in society and thus might be responsible for perpetuating an unjust set of social arrangements tends to be considered passé in contemporary political thought. The problem with such an idea is that it relies on a simplistic account of power, derived from the relation of command and obedience between an absolute sovereign and his subjects.

In modern societies, power operates in a much more complex manner: through normalisation rather than prohibition. Through the process of normalisation, individuals are implicated in their own subjection. Power comes from below, not from above. Social subordinates are not the dupes of a ruling class. Rather, all members of society are self-disciplining subjects. For these insights into the operation of power, an intellectual debt is commonly acknowledged to Michel Foucault; for it is Foucault who calls for the head of the king, for a reconceptualisation of power. And there are many political thinkers who have taken up the call, who have helped drag the king to the guillotine.

The particular conception of power Foucault has in mind when calling for the head of the king is not so much that exercised by Hobbes's Leviathan, although it includes this. Rather, it is the Marxist/New Left critique of social relations based on the domination of one group (for example, white, property-owning males) over another (non-white, property-less females). For this 'radical' tradition of thought, the 'project of creating a new and more just society' depends upon exposing those power relations masked by the ideology of a ruling group (Hartsock, 1990, p. 170). Progressive social change depends upon holding those 'in power' responsible for their role in perpetuating unjust social 
arrangements. Moreover, it depends upon those previously subordinated members of society assuming responsibility for recreating a more egalitarian world.

Certainly, in its more doctrinaire forms this kind of theorising, which relies on a critique of ideology, can 'do violence' to the complexity of social reality and can be 'falsely universalising' or 'totalising'. By contrast, Foucault's account of power is highly suggestive and seems able to capture some of the complexity of the processes through which power operates (see Barrett, 1991). However, Foucault is commonly criticised because the modern strategies of power he identifies appear to operate independently of responsible human agents (e.g. Habermas, 1985; Hartsock, 1990).

At the same time as he severs the king's head, it seems, Foucault severs the crucial conceptual relation between power and human responsibility. But it is this relation that gives the concept of power a place in our ethical vocabulary. To 'have' or 'exercise' power is to be morally and politically accountable for one's actions (including inactions) and their consequences on others. Where power is not attributable to human agency, there is no one to praise or blame, no one to hold to account for the way things are, no one, moreover, capable of political action. A Foucaultian conception of power appears to offer little scope for understanding humans as being responsible for the societies we create and the norms we live by. Consequently, 'cutting off the head of the king' in political theory might be less revolutionary than Foucault (1990, pp. 88- 89) supposes.

In this article, I explore the debate between theoretical 'monarchists' (e.g. Connolly, 1993; Hartsock, 1990) who want to insist on a clear relation between power and responsibility and Foucaultian 'revolutionaries' who suggest that responsibility might simply be another effect of power (e.g. Hindess, 1996; Barrett, 1991). Given the contingency of political action, I agree with Foucault that it is not always possible to attribute responsibility for the effects of power to a particular agent. However, to relinquish entirely the important connections the concept of power has to human responsibility within our ethical vocabulary, is to render the concept of power practically meaningless.

\section{'Off with his head!'}

Foucault (1990, pp. 94ff.) argues that the head of the king remains in political theory so long as we maintain a concept of power that: (i) is exercised by a sovereign (the state or a ruling class) and (ii) operates legislatively through prohibition. When conceived thus, power is understood to limit the freedom of those over whom it is exercised. Foucault wants to dispense with this 'juridicodiscursive' conception of power. According to him, the juridicodiscursive conception limits our understanding because it misconstrues the operation of power as a top-down process with a zero-sum distribution between 
rulers and ruled.

For Foucault, rather, power comes from below. Power is immanent in all social relations. No one is ever without power and everyone is subject to the effects of power, which are more often productive than prohibitive. While modern strategies of power are intentional they are 'nonsubjective':

' $\ldots$ there is no power that is exercised without a series of aims and objectives. But this does not mean that it results from the choice or decision of an individual subject; let us not look for the headquarters that presides over its rationality ...' (Foucault, 1990, p. 95).

By 'cutting off the head of the king', Foucault wants to reconceptualise power as existing beyond the state and its structures, pervading all our social relations. He wants to dispense with a conception of power that reduces all relations of power to a macro context between rulers and ruled (for example, according to class or gender). Further, he wants to understand the operation of power as having a logic of its own, independent of a conscious human will (Taylor, 1986, pp. 84ff.).

\section{'God save the king!'}

The juridico-discursive concept of power with which Foucault takes issue is recognisably that advocated by Stephen Lukes and other radical thinkers. It also includes liberal accounts of power such as those Lukes criticises. While liberals and radicals differ over what constitutes a legitimate exercise of power, they concur over the significance of the relation between power and responsibility for making such judgements.

According to William Connolly (1993, pp. 93ff.), two elements are common to our understanding of what constitutes an exercise of power by one agent over another:

(i) that both agents have a capacity for choice and (ii) that the recipient's capacity for choice or her ability to act as she chooses is in some way diminished by this act. Underlying this conception is our shared understanding that it is morally reprehensible to limit or impair the choice of others.

To reduce another's capacity for choice is to reduce her status as a responsible agent. At the same time as the recipient's responsibility is diminished, the weight of responsibility is shifted onto the agent exercising power. The notion of responsibility therefore forms a natural part of our vocabulary of power and invests the criteria of power with a normative dimension. Consequently, to attribute power to an agent amounts to something like an accusation, while to acknowledge that one exercises power is to acknowledge responsibility, which invites moral justification.

The ideal of autonomy is therefore fundamental to the relation between power 
and responsibility articulated by Connolly. In his view, our thinking about power:

'... draws upon prior conceptions about the characteristics of persons capable of forming intentions, acting upon beliefs and ideals, being guided by reasons, and worthy of being held responsible for the consequences of their own action' (Connolly, 1993, p. 94 - emphasis in original).

The presumption that it is wrong to compromise another's autonomy leads us to distinguish between ways of getting people to do things that are legitimate and those which are not and therefore constitute an exercise of power.

\section{'Power over' versus 'power to'}

Both Hartsock (1990, pp. 166-168) and Connolly (1993, p. 88) suggest that in order to take a critical perspective, one must conceptualise power as domination. According to them, the idea of power as 'power to' tends to reflect the concerns of those who have power rather than those who are subject to it. Consequently, considering power as enablement obfuscates the extent to which the possession of power is contingent on the domination of others.

However, there is a contradiction in this position since the ideal of autonomy on which it relies implicitly depends on a positive conception of power as a social good. As Ball (1993, p. 30) puts it, having power 'is the sine qua non of being able to act as a morally responsible human being'. According to Connolly (1993, pp. 93-94), what is wrong with a relation of 'power over' is that it impairs the recipient's capacity for choice or her ability to act as she chooses. By implication, emancipation from such a relation depends on empowerment of the individual. Autonomy, in other words, refers to an individual's relative 'power to' control her destiny, to be self-determining.

The positive correlation between power and autonomy suggests that power is properly understood as a 'capacity to effect outcomes' (Morriss, 1987, pp. 34ff.). As such, power may be exercised as domination but not necessarily so. To understand power in this way, it is not necessary to consider it something that an individual possesses. Rather, following Arendt (1970, p. 143), we should view power as derived from the capacity of humans to 'act in concert'. An individual only 'has' power for as long as she is empowered by a collective. Thus autonomy need not be perceived narrowly as freedom from restraint nor as selfrule. Rather, conceived as 'empowerment', the capacity to effect outcomes, the autonomy of an individual is revealed as dependent upon the co-operation of others.

\section{Political responsibility and moral autonomy}


As Morriss (1987, pp. 37ff.) points out, issues of responsibility enter into discussions of power primarily in moral contexts in which we seek to attribute praise or blame to concrete agents for their actions or inactions. In this context, while it is necessary to identify an agent as having the capacity to effect outcomes in order to establish that agent's responsibility for an action/inaction, having power is not morally reprehensible in itself. Indeed, the more people who are empowered the better. What is open to moral appraisal is how one exercises (or chooses not to exercise) power.

In contrast, the context in which radicals discuss power is principally an evaluative one, concerning the distribution of power in society. This essentially involves two not necessarily related considerations: (i) how much power individuals have to satisfy their needs and (ii) the extent to which some people are subject to others. In Morriss's (1987, pp. 41-42) view, the role of the social critic is to 'evaluate [a] society, not to distribute praise or blame to people'.

As Connolly (1983, p. 123) recognises, in accounting for the effects of power, which may operate institutionally and unconsciously, it is all too often impossible to establish where structural biases stop and collective responsibility begins. This difficulty arises from the contingency of political action. While there may be no particular agent deliberately organising a society hierarchically according to an ascribed status (gender, for example), the persistence of such structures remain a product of human agency. To differentiate structural biases from effects of power (as liberals tend to do; e.g. Connolly, 1993, p. 123) on the basis that it is not possible to identify a responsible agent seems unnecessarily to limit our understanding of the way power operates in society. Conversely, however, to insist (as radicals have tended to; e.g. Lukes, 1974, p. 56) that where effects of power are observable there must be a particular responsible agent, a 'sovereign', also seems misplaced.

It appears then, that the concept of power depends for its evaluative content less on its relation to responsibility (in terms of its exercise) than on its relation to the ideal of autonomy (in terms of the extent to which this is realised for all members of society). Thus Foucault's effort to divest the concept of power from its association with a sovereign does not necessarily divest the concept of its relation to human responsibility. However, Foucault also wants to dispense with the norm of autonomy as the basis for determining what constitutes a legitimate exercise of power. While the Foucaultian conception of power helps overcome a crude distinction between a perpetrator-class and victim-class in society (which 'juridico-discursive' conceptions have sometimes yielded), this appears to be achieved at the cost of understanding individuals as creative social agents.

\section{Power/knowledge}

To grasp how Foucault calls the fact and value of individual autonomy into 
question we must appreciate the extent to which he considers knowledge to be implicated in relations of power. In Discipline and Punish and The History of Sexuality (Volume 1), Foucault inverts our Enlightenment understanding of the relation between power and knowledge. We commonly view knowledge as a vehicle of emancipation. However, for Foucault $(1977$, p. 28) the production of knowledge or 'truth' is both an effect and a source of power.

So, for instance, Foucault rejects the story of 'sexual liberation' as a struggle through which modern western societies have cast off a repressive Victorian sensibility that placed irrational prohibitions on our sexual practices. Rather, he argues that sexuality is 'far more a positive product of power than power was ever a repression of sexuality' (Foucault, 1980, p. 120). That is, it was through its putting into discourse that sexuality was constructed, thus creating social norms that constitute sexuality as part of the individual's identity (i.e. as normal or deviant). In this analysis, the procedure of confession is not about uncovering an individual's inner truth but about disciplining the individual through the internalisation of a truth-regime.

Modern strategies of power, then, operate through normalisation rather than prohibition. For Foucault, human bodies are subjugated by turning them into objects of knowledge. Disciplinary power is a form of knowledge that maximises the efficiency of human bodies (productive capacity, literacy and so on). At the same time as discipline 'increases the forces of the body (in economic terms of utility)', however, it 'diminishes these same forces (in political terms of obedience)'. Discipline, therefore, creates 'docile bodies'. Through the acquisition of disciplinary knowledge (i.e. the internalisation of norms), the individual 'becomes the principle of his own subjection' (Foucault, 1980, pp. 138 and 203).

Foucault illustrates how this comes about through the metaphor of the panopticon. The panopticon is a design for a prison, with a circular block of inward-facing cells built around a central observation tower. From the tower, inmates are totally visible at all times, but they can never be sure whether they are being observed or not. However, due to their knowledge that they might be being watched, they become compliant 24 hours a day. Like the inmates of the panopticon, individuals in modern societies become self-policing subjects, internalising codes of behaviour rather than having them enforced by an extrinsic relation of power.

\section{Responsibility as an effect of power}

Foucault's understanding of the relation between responsibility and power, then, is strikingly different to that presented by either radicals or liberals. Foucault rejects the idea of attributing responsibility for the exercise of 'power over' to a dominant group, as radicals would have it. Instead, he insists that power is 
immanent in all our social relations and mediated through knowledge. Everyone both has power and is subject to power. Moreover, he inverts the conventional liberal understanding of responsibility as contingent on an agent's 'power to'. Instead, Foucault's analysis suggests that the extent to which an individual is 'in power', and hence responsible, is an indication of his subjection. For, as Barry Hindess (1996, p. 131) points out, the liberty of subjects is itself an indispensable element of disciplinary power, which trains individuals in the 'dispositions and values of responsible autonomy'.

It follows that Foucault neither makes a morally necessary presumption of the autonomy of individuals as liberals do, nor does he take individual autonomy as an ideal by which to criticise the status quo, as do radicals. Rather, he considers both the norm of the autonomous individual and the extent to which this is realised as an effect of disciplinary power (Hindess, 1996, p. 149). In contrast to the radical critique of ideology (e.g. instrumental reason of the Frankfurt School), Foucault does not conceive of discipline as an oppressive rationality from which we must be emancipated. This is because, in his view, there is no essential self to emancipate, nor truth to uncover. Given that power is socially ubiquitous, emancipation from a dominant ideology could only amount to the replacement of one regime of truth with another (Taylor, 1986, p. 94).

\section{Should we spare the king's head?}

As Charles Taylor points out, Foucault's notion of power without subjectivity is not incomprehensible. One can indeed recognise a strategic logic of contexts that is not attributable to any conscious purpose. The idea of power does not require that we attribute responsibility for its effects to a particular agent. However, Taylor (1986, p. 90) is right to point out that the concept of power in its most minimal sense must refer to 'a process in some way related to human agency. Otherwise the term loses all meaning.' By contrast, reading Foucault, power seems to be invested with an agency of its own. Thus, 'power can retreat here, re-organise its forces, invest itself elsewhere ... and so the battle continues' (Foucault, 1980, p. 56).

What is ultimately unsatisfactory about the way Foucault conceptualises power is not so much that he is unwilling to attribute responsibility for its exercise/distribution to a social agent. Rather, it is that he divests from his discussion of power the related notions of truth and freedom. As Taylor (1986, p. 91) puts it, such an endeavour can only confound us because power "belongs to a semantic field from which "truth" and "freedom" can not be excluded'.

In short, even 'productive' power only makes sense to the extent that it limits or enables human autonomy. To consider both truth and freedom to be effects of power is contradictory, for as such they can only amount to ideology and domination. This emerges in Foucault's own account. The fact that the power he 
describes is disguised implies a truth-claim in his telling of what is really going on. As Taylor eloquently puts it:

' $\ldots$ in offering us a new way of reappropriating our history, and in rescuing us from the supposed illusion that the issues of the deep self are somehow inescapable, what is Foucault laying open for us, if not a truth which frees us for self-making?' (Taylor, 1986, p. 99).

While Foucault offers us many rich insights into the mechanisms of control that operate in modern societies, it is his refusal to accept autonomy as a positive human value which undermines the effectiveness of his theory for understanding the human capacity to transform the social world.

While the effects of power must be seen to stem from human agency, the unpredictability of action means that these may not be attributable to deliberate human intention. In this sense, Foucault is right to call for the king's head. Paradoxically, however, the contingent nature of politics points to the urgency of assuming responsibility for the society we create and the norms by which we live. While we may not be able to control the outcomes of collective action, we must recognise the extent to which the maintenance of common norms and of relations of domination and subordination in society depend on the collective support of particular human agents. It is above all this sense of human beings as creative agents both of the self and of the world they share that is missing in Foucault.

\section{Note}

Thanks to Jonathan Hearn, Russell Keat, Bregham Dagleish, John Glassford and the two anonymous reviewers for their comments.

\section{References}

Arendt, H. (1970), 'On Violence' in Crises of the Republic, New York and London: Harcourt Brace Jovanovich.

Ball, T. (1993), 'Power' in R.E. Goodin and

P. Pettit (eds.), A Companion to Contemporary Political Philosophy, Oxford:

Blackwell. Barrett, M. (1991), The Politics of Truth: From Marx to Foucault,

Cambridge: Polity.

Connolly, W. (1993), The Terms of Political Discourse (3rd edn), Oxford: Martin Robertson.

Foucault, M. (1977), Discipline and Punish: The Birth of the Prison (trans. A. Lane), London: Penguin.

Foucault, M. (1980), Power/Knowledge: Selected Interviews and Other Writings 19721977 (ed. C. Gordon), New York and London: Harvester Wheatsheaf. 
Foucault, M. (1990), The History of Sexuality, Volume 1: An Introduction (trans. R. Hurley), London and New York: Penguin.

Habermas, J. (1985), 'Some Questions Concerning the Theory of Power: Foucault Again' in The Philosophical Discourse of Modernity, Cambridge: Polity.

Hartsock, N. (1990), 'Foucualt on Power: A Theory for Women?' in L.J. Nicholson (ed.), Feminism/Postmodernism, London: Routledge.

Hindess, B. (1996), Discourses of Power: From Hobbes to Foucault, Oxford: Blackwell.

Lukes, S. (1974), Power: A Radical View, London: Macmillan.

Morriss, P. (1987), Power: A Philosophical Analysis, Manchester: Manchester University Press.

Taylor, C. (1986), 'Foucault on Freedom and Truth' in D.C. Hoy (ed.), Foucault: A Critical Reader, Oxford: Blackwell. 


\section{University Library}

\section{- M M I E R R A A gateway to Melbourne's research publications}

Minerva Access is the Institutional Repository of The University of Melbourne

Author/s:

Schaap, Andrew

Title:

Power and responsibility: should we spare the king's head?

Date:

2000

Citation:

Schaap, A. (2000). Power and responsibility: should we spare the king's head? Politics, 20(3), 129-135.

Publication Status:

Published

Persistent Link:

http://hdl.handle.net/11343/34375 